\title{
An Empirical Study on DBT Awareness
}

\author{
V. Selvam ${ }^{1}$ \\ G. Velmurugan² \\ 1 Professor of Commerce, SSL, VIT University, Vellore 632 014, Tamil Nadu, India \\ 2 Professor of Commerce, SSL, VIT University, Vellore 632 014, Tamil Nadu, India \\ Correspondence: V. Selvam, Professor of Commerce, VIT University, Vellore 632 014, Tamil Nadu, India \\ Email:veernsel@gmail.com
}

Doi:10.5901/mjss.2015.v6n5p229

\begin{abstract}
The Direct Benefit Transfer (DBT) is a social security scheme launched by the government of India, with a prime objective to transfer of cash subsidy directly to the people living below poverty line and entitlements directly to the beneficiary, whose identification would be verified on the base of 'Aadhaar Card' linked with the bank account. Observably, this foresighted steps has been taken by the government of India after experiencing so many years of hurdles such as unnecessary delays, leakages and diversion of benefits which take place while providing subsidy to the needy people. In a country like India where more than $25 \%$ people are living below poverty line and the benefit of, Central and State Governments sponsored schemes are not reaching them. In spite of spending huge amount and deploying substantial workforce these poor classes are still struggling for their day to day needs like food, shelter, clothing, health, education etc. Various reasons can be mentioned behind this imbalance but it is a proven fact that all is not well. Certain major shortcomings in this regard are non-scientific method for the identification of the beneficiary, lack of proper and effective channels of distribution, lack of interest of implementation of concerning authority, delay in delivery of service, reaching beneficiaries not at its doorsteps and lack of awareness on the benefit of direct benefit transfer. Based on the above backdrop, this paper investigates the public awareness on direct benefit transfer in Vellore District, Tamil Nadu. The findings of this empirical study emphasis the public awareness about the direct benefit transfer scheme and its implication in India.
\end{abstract}

Keywords: Direct Benefit Transfer, Public Awareness, Government Schemes and Aadhaar Card

\section{Introduction}

The government must be responsible regarding the needs and demands of the people. An effective government always has concern over the public related issues. The government of India launched various types of welfare schemes and programmes for its people under whom they are provided subsidies, scholarships to students, benefits to illiterate women and micro credit to poor women section. Until December 2012, the beneficiaries were getting benefits which had to pass through hands of various intermediaries that had become responsible for leakage and delay when later on analyzed by the government. Consequently, the welfare schemes did not achieve their desired targets which were set by the government. Due to such reasons and inevitable hurdles the benefits which were supposed to reach the needy people could not happen. So, to overcome and resolve this problem the Government of India has launched "Direct Benefit Transfer (DBT) Scheme" on January $1^{\text {st }}, 2013$. The main objective of the programme is to transfer the government subsidies directly to Indian citizens who are living below poverty line. The primary aim of this DBT programme is to remove constrains and open up distribution of Central Government sponsored funds to the beneficiary through bank account using Aadhaar Card. With this background, this research paper analyses the issues relating to the public awareness about DBT in Vellore District, Tamil Nadu.

\section{Concept of Direct Benefit Transfer}

Transfer of cash subsidy directly to the people living below poverty line. The government gives subsidy to enable common man to have access to the basic necessities like fuel and food grains at affordable prices. Under this scheme, the covered beneficiaries get the amount directly in their bank accounts. 


\section{DBT at Global Level}

In order to reduce poverty at glob many countries introduced Direct Benefit Transfer scheme. The Government of India realized the importance and benefit of DBT and introduced this scheme all over the states. Different countries adopted different methodology to distribute this scheme. In many countries they distribute this scheme under the name of Conditional Cash Transfer Scheme (CCTS). Majority of the Asian countries have started to exercise this scheme and also in some countries like Malawi, Morocco, Kenya and South Africa. It is introduced eighteen countries in Caribbean and Latin America had already implemented CCTS.

\section{Benefits from DBT}

In India there are many DBT schemes in existence. The only addition to the existing cash transfer scheme is the addition of one more stage of verification to it that is "Aadhaar card number". The major benefits of DBT present in it are:

1. DBT is linked with usage of both Aadhaar card and biometric verification which will remove the problem of duplication of beneficiaries.

2. Benefits would possibly reach beneficiary on every first of every month and no intermediaries.

3. An intense network, the bank would ensure that the cash must reach the beneficiary at its doorstep.

4. By use of Aadhaar based micro ATM networks, the cash transfers that take place inside India can now be performed instantly with lower cost.

\section{DBT - Pilot Study}

Table 1 indicates the basic profile of the twenty selected DBT districts in India. It clearly predicts that the total coverage of DBT through Aadhaar in almost all the districts of Andhra Pradesh, and nearly $80 \%$ coverage in the state of Karnataka districts like Tumkur and Mysore. So far only one-fourth of the population has been covered under DBT. The households having mobile phones indicates even more difference that is 36\% in East Nimar and $86 \%$ in North East Delhi. With regard to households availing banking facilities that is from 39\% in East Godavari to $81 \%$ in SBS Nagar. Moreover, the selected District profile for the first round of DBT through Aadhaar were given in Table 1 for clear understanding.

Table 1. First Round Selected District Profile Relating to DBT in India

\begin{tabular}{|l|c|c|c|c|c|c|}
\hline District & $\begin{array}{c}\text { Total } \\
\text { Population }\end{array}$ & $\begin{array}{c}\text { Total Number } \\
\text { of Enrolment }\end{array}$ & $\begin{array}{c}\text { Share of Enrolment } \\
\text { (Population In \%) }\end{array}$ & $\begin{array}{c}\text { Households } \\
\text { (getting banking } \\
\text { Services in \%) }\end{array}$ & $\begin{array}{c}\text { Households } \\
\text { (Having mobile } \\
\text { phones in \%) }\end{array}$ & $\begin{array}{c}\text { Households } \\
\text { (With no specified } \\
\text { Assets* in \%) }\end{array}$ \\
\hline Dharwad & $1,846,993$ & 867,877 & 47 & 72 & 65 & 13.9 \\
\hline Tumkur & $2,681,449$ & $2,333,552$ & 87 & 49 & 50 & 20.0 \\
\hline Mysore & $2,994,744$ & $2,597,470$ & 87 & 50 & 63 & 13.7 \\
\hline Hyderabad & $4,010,238$ & $5,057,244$ & 126 & 59 & 80 & 3.1 \\
\hline Anantpur & $4,083,315$ & $3,530,805$ & 86 & 63 & 58 & 22.6 \\
\hline Chittoor & $4,170,468$ & $3,488,528$ & 84 & 65 & 58 & 20.8 \\
\hline East Godavariri & $5,151,549$ & $4,405,590$ & 86 & 39 & 47 & 17.3 \\
\hline Alwar & $3,671,999$ & 763,178 & 21 & 59 & 73 & 15.2 \\
\hline Ajmer & $2,584,913$ & 657,717 & 25 & 77 & 72 & 14.5 \\
\hline Udaipur & $3,067,549$ & 662,785 & 22 & 61 & 51 & 36.7 \\
\hline Harda & 570,302 & 414,042 & 73 & 45 & 55 & 30.0 \\
\hline Hoshangabad & $1,240,975$ & 872,427 & 70 & 50 & 53 & 25.5 \\
\hline East Nimar & $1,309,443$ & $1,029,906$ & 79 & 49 & 36 & 43.2 \\
\hline Puducherry & 946,600 & 856.130 & 90 & 64 & 77 & 5.1 \\
\hline Chandigarh & $1,054,686$ & 705,370 & 67 & 80 & 83 & 2.3 \\
\hline SBS Nagar & 614,362 & 30,421 & 5 & 81 & 76 & 3.2 \\
\hline NW Delhi & $3,651,261$ & $2,809,152$ & 77 & 73 & 82 & 4.0 \\
\hline NE Delhi & $2,240,749$ & $1,389,917$ & 62 & 70 & 86 & 2.4 \\
\hline Daman \& Diu & 242,911 & 131,457 & 54 & 65 & 82 & 7.6 \\
\hline
\end{tabular}

- $\quad$ Assets includes Computer, Radios, TV, Telephone, Four-Wheeler, Two-Wheeler and Bicycles.

Source: Census of India, population and household data and Aadhaar website for enrolment. 


\section{Review of Literature}

Fathima (2014) pointed out that central government of India would fetch fruitful results to the Indian economy provided proper implementation is made. This will not only make inflow of cash to the weaker sections but also strengthen the bank penetration to the remote and backward areas of India. Farhina Sardar Khan (2014) argued that the initiative steps taken by the government of India for introducing direct cash transfer to the beneficiary personal savings account is in itself a milestone in the history of economic yet a lot of work is still needed to make it flawless in its implementation.

Karen Macours (2013) stated that adequate evidence from the studies has substantiated the argument that cash transfer has helped to break the poverty cycle by enabling human capital formation among the youth of the poor families. Partha Mukhopadhyay (2013) studied that the real potential lies in shifting thinking from targeting to traceability and mitigating transactional instrumentalism in market transactions. Suyash Rai (2013) analyzed that as long as operation is satisfactory, the basic direct cash transfer scheme that has initiated, and the direct non-cash transfer of welfares based on Aadhaar-based verification, are good thoughts. Palanithurai (2013) stated that the people of India has less awareness about this scheme. People who are living in the rural and remote villages are totally unaware from the decision taken at the capital. They are not being provided the necessary background data and detailed information about the various programmes and schemes implemented by the government.

\section{Problem of the Study}

In a country like India where more than $25 \%$ people are living below poverty line, the benefit of Central and State Governments sponsored schemes are not reaching them. In spite of spending huge amount and deploying substantial workforce these poor classes are still struggling for their day to day needs like food, shelter, clothing, health, education etc. Various reasons can be mentioned behind this imbalance but it is a proven fact that all is not well. Certain major shortcomings in this regards are non-scientific method for the identification of the beneficiary, lack of proper and effective channels of distribution, lack of interest of implementation of concerning authority, excessive intermediaries and delay in delivery of service, precaution of beneficiaries, reaching beneficiaries not at its doorsteps, more intermediaries between the government and beneficiaries and public are not aware of government benefits including DBT to rural people who are living below poverty line. Based on the above statement of problem, it is necessary to study the public awareness on benefits of direct benefit transfer in Vellore District, Tamil Nadu, India.

\section{Rsesearch Hypothesis}

Ho: There is no significant association between age and public awareness about the direct benefit transfer in India. H1: There is significant association between age and public awareness about the direct benefit transfer in India.

\section{Objectives of the Research Study}

1. To find out the personal profile of the respondents.

2. To identify the public awareness about direct benefit transfer in the study area.

\section{Methodology}

This study is based on empirical in nature. Primary data were used to collect the questionnaire from the respondents who are residing in Vellore District to find out their awareness on direct benefit transfer and secondary data were collected through published source like journals, magazines, newspapers, annual reports and working papers etc.

Convenience sampling method was used for this study. 150 questionnaires were distributed and only 147 were received from the respondents and finally the researcher has taken only 127 questionnaire for consideration and the balance 20 questionnaires were not considered for analysis and discussion. The collected questionnaire deals with two sections.

Section A contains personal details while section B deals with public awareness on direct benefit transfer with five point Likert's scaling questions. The respondents were asked to read the statement carefully and rate the statement ranging from 1 (strongly disagree) to 5 (strongly agree). The statistical calculations like frequency distribution, percentage analysis and one way variance analysis (ANOVA) were used to find out the public awareness on direct benefit transfer.

In order to analyze data SPSS version 16 windows was used. 


\section{Realiability Test}

In order to find out the internal consistency among the variables the researcher applied Cronbach's alpha reliability test and it finally revealed 0.764 as Cronbach's alpha value. According to (Hair, et. at. 1998) normal accepted limit is 0.70. Therefore the results clearly shows that there is a strong internal consistency and reliability among the variables for the study.

\section{Limitations of the Study}

Sample size is restricted to 127 only. All the samples were also collected only from the respondents who are residing in and around Vellore District. The major limitations of the study is time and cost. The results of the study may not be universal to other similar type of the study conducted in some other district of Tamil Nadu. The period of study is limited to three months i.e., from January 2015 to March 2015.

\section{Data Analysis and Interpretation}

\subsection{Frequency and Percentage Analysis}

The data relating to respondents personal profile were given below in Table 2.

Table 2. Personal profile of the respondents

\begin{tabular}{|c|c|c|c|}
\hline Parameters & Category & Frequency & Percentage \\
\hline \multirow[t]{3}{*}{ Gender } & Female & 30 & 24 \\
\hline & Male & 97 & 76 \\
\hline & Total & 127 & 100 \\
\hline \multirow[t]{3}{*}{ Nativity } & Urban & 36 & 28 \\
\hline & Rural & 91 & 72 \\
\hline & Total & 127 & 100 \\
\hline \multirow[t]{5}{*}{ Age } & 18 to 20 & 58 & 45 \\
\hline & 21 to 23 & 55 & 43 \\
\hline & 24 to 26 & 7 & 6 \\
\hline & 27 to 30 & 7 & 6 \\
\hline & Total & 127 & 100 \\
\hline \multirow[t]{6}{*}{ Awareness on DBT } & Strongly agree & 15 & 12 \\
\hline & Agree & 47 & 37 \\
\hline & Neither agree nor disagree & 31 & 24 \\
\hline & Disagree & 28 & 22 \\
\hline & Strongly disagree & 6 & 5 \\
\hline & Total & 127 & 100 \\
\hline
\end{tabular}

Data Source: Primary

It is inferred that, from the total of 127 respondents only 30 respondents are female and 97 respondents are male. $72 \%$ of the respondents are from rural place and $28 \%$ of the respondents are from urban place. $46 \%$ of the respondents fall under 18 to 20 years of age. $12 \%$ of the respondents strongly agreed and $37 \%$ of the respondents were agreed about the awareness on DBT.

\subsection{Variance Analysis (One Way Annova)}

The data relating to age and public awareness on DBT of the respondents were presented in Table 3. 
Table 3. Cross Tabulation between Age and Public awareness on DBT

\begin{tabular}{|l|c|c|c|c|c|c|}
\hline \multirow{2}{*}{ Age } & \multicolumn{5}{|c|}{ Awareness on DBT } & \multirow{2}{*}{ Total } \\
\cline { 2 - 6 } & SD & DA & NAND & AG & SA & \\
\hline 18 to 20 & 0 & 0 & 0 & 43 & 15 & 58 \\
\hline 21 to 23 & 0 & 20 & 31 & 4 & 0 & 55 \\
\hline 24 to 26 & 0 & 7 & 0 & 0 & 0 & 7 \\
\hline 27 to 30 & 6 & 1 & 0 & 0 & 0 & 7 \\
\hline Total & $\mathbf{6}$ & $\mathbf{2 8}$ & $\mathbf{3 1}$ & $\mathbf{4 7}$ & $\mathbf{1 5}$ & $\mathbf{1 2 7}$ \\
\hline
\end{tabular}

Data Source: Primary. (SD: Strongly Disagree, DA: Disagree, NAND: Neither Agree Nor Disagree, AG: Agree, SA: Strongly Agree)

The data pertaining to public awareness on DBT of the respondents were presented in Table 4.

Table 4. Variance Analysis (One Way ANOVA)

\begin{tabular}{|l|c|c|c|c|c|}
\hline & Sum of squares & Degree of freedom & Mean square & F-value & Sig. - value \\
\hline Between Groups & 70.454 & 4 & 17.613 & 182.620 & $.001^{\star \star}$ \\
\hline Within Groups & 11.767 & 122 & .096 & & \\
\hline Total & $\mathbf{8 2 . 2 2 0}$ & $\mathbf{1 2 6}$ & & & \\
\hline
\end{tabular}

Data Source: Primary, ${ }^{*}$ at $5 \%$ level of significant

\section{Findings}

1. It is also revealed from table 3 that 43 respondents who fall under the age category 18 to 20 agreed that they were aware of DBT and 15 respondents who fall under the age category 18 to 20 strongly agreed that they were aware of DBT.

2. It is inferred from the above table 4, the calculated value of one way ANOVA is 0.001 , which is less than the hypothetical value $(a=0.05)$. Hence, the null hypothesis is not accepted. So, there is significant association between age and public awareness on DBT in Vellore District.

\section{Conclusion}

This study concludes that the awareness about DBT is minimum with the respondent who resides in and around Vellore District. They are not aware of what is happening around them like the announcements of schemes of central government of India. They are not being provided the required information about the DBT. Village panchayats nearer to them are not able to provide the required information. So the central, state government and village pancyayats should jointly take some concrete steps and ensure that people understand the spirit of DBT. Hence, awareness among the rural people who are below poverty line with respect to these schemes is highly required to improve the standard of living.

\section{Suggestions}

People should be given proper awareness about the scheme by the village panchayats. This can be achieved through the effective participation of the panchayat and the educated youth in the villages. Proper awareness programme can be conducted at village level through educational institutions, non-governmental organizations; self-help groups so that the government can eliminate the misconceptions about the scheme to be implemented in the villages. The officials' in charge for enrollment can give a clear picture about the technology involved in this scheme as well. This will remove all unnecessary fear in the minds of the public. Media's involvement and dissemination about the DBT schemes is also highly pivotal. 


\section{References}

Carmines, E, and Zeller, R, (1979), "Reliability and Validity Assessment", Sage University Paper, Sage Publications, Beverly Hills, www.sagepub.in

Desti Kannaiah and V. Selvam, (2014), "Impact of FDI in Retailing: An Empirical Analysis on Perception of Unemployed Youth on Employment Opportunities in India", International Journal of Economics and Finance, Vol.6, No. 11, pp.9-20. doi:10.5539/ ijef.v6n11p, URL: http://dx.doi.org/10.5539/ijef.v6n11p.

Farhina Sardar Khan, (2013), "Direct Benefit Transfer: Strong Initiative towards the Empowerment of Citizens", Economic Challenger, Vol.62, No.16, pp.52-59. http://economicchallenger.net

Hair, J, Anderson, R, Tatham, R and Black, W, (1998), "Multivariate Data Analysis", Prentice-Hall International Edition, New Jersey, www.prenticehall.com

Jairam Ramesh and Varad Pande, (2013), "The Direct Benefits Transfer: No Need for Hype but Certainly a Hope", Yojana, Vol.17, pp.810, http://www.yojana.gov.in

Joseph Hanlon, Armando Barrientos and David Hulme, (2010), "Just Give Money to the Poor: The Development Revolution from the Global South", USA, Kumarian Press.

Kapur A and Chowdhury A, (2011), "Integrated Public Distribution System, GOI Budget Briefs 2011-12", Budget Briefs - TTPDs, Vol.3, No.7. (http://ssrn.com/paper=1790987).

Mukhopadhyay and Partha, (2013), "What Can We Expect From Direct Benefit Transfers", Yojana, Vol.57. http://www.yojana.gov.in

NIPFP Macro/Finance, (2012), "A Cost-Benefit Analysis of Aadhaar", National Institute of Public Finance and Policy, November 9 (http://macro_nance.nipfp.org.in).

Palanithurai, (2013), "Direct Benefit Transfer: Perspectives of Stakeholder", South Asian Journal of Socio-Political Studies, Vol.14, No.1, pp.6-10, http://www.sajospsindia.com

Planning Commission, Government of India, "Information and Guide on Direct Benefit Transfer", (planningcommission.nic.in /sectors/dbt/DBT_NIC_BLMS.pdf).

Partha Mukhopadhyay, (2013), "What Can We Expect from Direct Benefit Transfers?" Yojana, Vol.17, pp.23-30, http://www.yojana. gov.in

Pravakar Sahoo, (2013), "Direct Benefit Transfer: Panacea to Remove Poverty and Inequality in India? Yojana, Vol.17, pp.45-50, http://www.yojana.gov.in

Richard Akresh, Damien de Walque and Harounan Kazianga, (2013), "Cash Transfers and Child Schooling: Evidence from a Randomized Evaluation of the Role of Conditionality", Policy Research Working Paper 6340, Washington DC, The World Bank.

Rathod, Saikumar, Prasad Shiva Krishna, Arelli and Debashis Saha, (2012), "An Aadhar-Based Mobile Money Framework for Financial Inclusion in India", Working Paper Series, WPS No.692, January. https://facultylive.iimcal.ac.in/.../files/WPS 692_0.pdf

Suyash Rai, (2013), "Direct Transfer of Benefits: What Lies Ahead", Yojana, Vol.17, pp.51-55, http://www.yojana.gov.in

Times News Network, (2014), "Direct cash subsidy: Challenges for implementation", Business Standard, 25 $5^{\text {th }}$ April, http://www.businessstandard.com 